\title{
Perceptions of Physics Teacher Candidates towards Creative Thinking Skills and Creative Materials
}

\author{
Güner TURAL ${ }^{1 *}$
}

${ }^{1}$ Ondokuz Mayıs University, Department of Mathematics and Science Education, Samsun, Turkey

\begin{tabular}{l} 
ARTICLE INFO \\
\hline Article History: \\
Received \\
16.05.2016 \\
Received in revised \\
form 28.03 .2017 \\
Accepted 09.04.207 \\
Available online \\
30.06.2017
\end{tabular}

30.06.2017

\begin{abstract}
The aim of this study is to determine perceptions of physics teacher candidates towards their creative thinking skills and the creative materials. Also it is aimed to get views of physics teacher candidates about effect of instructional technology and material design course on creative thinking processes. The study group is composed of 57 physics teacher candidates. Information form and semi-structured interview form were used as a data collection tool. The data obtained from the information form was presented as frequency and percentage. Descriptive analysis approach as a qualitative data analysis was used for obtained data from interview form. Results showed that physics teacher candidates mostly perceive themselves as having "moderately creative" thinking skill. Creative instructional material mostly evokes to physics teacher candidates features as to be original, attractive and to serve the purpose.
\end{abstract}

(C) 2017 AUJES. All rights reserved

Keywords:

Physics teacher candidate, creative thinking skill, creative material

\section{Extended Abstract}

\section{Purpose}

It is important to determine perceptions of teacher candidates towards their creative thinking skill on behalf of creation and organization of learning environments that will contribute to the development of these skills.

The purpose of this study is to determine perceptions of physics teacher candidates towards their creative thinking skills and the creative materials. Also it is aimed to get views of physics teacher candidates about effect of instructional technology and material design course on creative thinking processes.

\section{Method}

This study is a descriptive research. The study group is composed of 57 physics teacher candidates. Information form and semi-structured interview form were used as a data collection tool. The data obtained from the information form was presented as frequency and

"Corresponding author's address: Ondokuz Mayıs University, Faculty of Education, Department of Mathematics and Science Education, Samsun

e-mail:guner.tural@omu.edu.tr 
percentage. Descriptive analysis approach as a qualitative data analysis was used for obtained data from interview form.

\section{Results}

The number of physics teacher candidates perceived themselves as "moderately creative" was the most. Creative material mostly express to teacher candidates to be original. Teacher candidates' evaluation of their materials in terms of creativity, the number of teacher candidates that found their materials as creative was the most. Teacher candidates think that instructional technology and material design course effects creative thinking processes positively.

\section{Discussion and Conclusion}

Creative instructional material mostly evokes to physics teacher candidates features as to be original, attractive and to serve the purpose. Teacher candidates' evaluation of their materials in terms of creativity showed that number of teacher candidates found their materials as creative was the highest and the most reason was their attractive features. The reason of the most teacher candidates that find their material uncreative was their lack of original.

To move up perceptions of teacher candidates towards creative thinking skill than middle level, the creation of educational environment to develop these skills is important. Especially instructional technology and material design course contained in the Education Faculty programs can allow teacher candidates to be aware their creative thinking skills and to develop it. Indeed, some studies (Acer, 2011; Çakır, 2010; İnce, Usta and Çığır Dikyol, 2010; Sönmez et. al., 2006) conducted in the literature with teacher candidates that received instructional technology and material design course reached results supporting this view. 


\title{
Fizik Öğretmen Adaylarının Yaratıcı Düşünme Becerilerine ve Yaratıcı Materyallere Yönelik Algıları
}

\author{
Güner TURAL ${ }^{*}$
}

${ }^{1}$ Ondokuz Mayıs Üniversitesi, Matematik ve Fen Bilimleri Eğitimi Bölümü, Samsun, Türkiye

MAKALE BILGI

Makale Tarihçesi: Alındı 16.05.2016

Düzeltilmiş hali

alındı 28.03.2017

Kabul edildi

09.04.2017

Çevrimiçi yayınlandı 30.06.2017

\section{ÖZET}

Bu çalışmanın amacı fizik öğretmen adaylarının yaratıcı düşünme becerilerine ve yaratıcı materyallere yönelik algılarını belirlemektir. Ayrıca öğretim teknolojileri ve materyal tasarımı dersinin yaratıcı düşünme süreçlerine etkisine ilişkin fizik öğretmen adaylarının görüşlerini almaktır. Araştırmanın çalışma grubunu 57 fizik öğretmen adayı oluşturmaktadır. Veri toplama aracı olarak bilgi formu ve yarı-yapılandırılmış görüşme formu kullanılmıştır. Bilgi formundaki sorulardan elde edilen veriler frekans ve yüzde olarak sunulmuştur. Görüşme formu sorularından elde edilen verilerde nitel veri analizlerinden betimsel analiz yaklaşımı esas alınmıştır. Bulgular fizik öğretmen adaylarının kendilerini çoğunlukla "orta düzeyde yaratıcı" düşünme becerisine sahip olarak algıladıklarını göstermiştir. Bir öğretim materyalinin yaratıcı olması; fizik öğretmen adaylarına en fazla orijinal olması, dikkat çekici olması ve amaca hizmet etmesi özelliklerini çağrıştırmaktadır.

(C) 2017 AUJES. Tüm hakları saklıdır

Anahtar Kelimeler:

Fizik öğretmen adayı, yaratıcı düşünme becerisi, yaratıcı materyal

\section{Giriş}

Günümüzün hızla değişen ve gelişen dünyası; çağı yakalayabilen, problemlere çözüm üretebilen üst düzey düşünme becerilerine sahip bireylerin yetişmesini önemli kılmaktadır. Gelecek nesilden beklenen bu niteliklerin sağlanabilmesi, onları yetiştirecek olan öğretmenlerin de nitelikli yetişmelerini gerektirmektedir.

Mevcut öğretim programları öğrencilerin öğrenmede aktif olabilecekleri, araştırmalarına, sorgulamalarına, üretmelerine olanak sağlayan uygulama ortamlarını öngörmektedir. Benzer şekilde öğretmen yetiştiren programlarda da geleceğin öğretmenleri olacak adaylara bu tür ortamların sunulması önemlidir. Öğretmen yetiştiren programlarda zorunlu ders olarak konulan "Öğretim Teknolojileri ve Materyal Tasarımı" dersi öğretmen adaylarını öğrenme sürecinde aktif kılan, birden çok duyu organlarını kullanarak onlara bilgi ve becerilerini uygulama fırsatı sunan dersler arasında yer almaktadır. Bu dersin içeriğini; öğretim teknolojisi ile ilgili

\footnotetext{
${ }^{*}$ Sorumlu yazarın adresi: Ondokuz Mayıs Üniversitesi, Eğitim Fakültesi, Matematik ve Fen Bilimleri Eğitimi Bölümü, Samsun e-mail:guner.tural@omu.edu.tr
} 
kavramlar, çeşitli öğretim teknolojilerinin özellikleri, öğretim teknolojilerinin öğretim sürecindeki yeri ve kullanımı, okulun ya da sınıfın teknoloji ihtiyaçlarının belirlenmesi, uygun teknoloji planlamasının yapılması ve yürütülmesi, öğretim teknolojileri yoluyla iki ve üç boyutlu materyaller geliştirilmesi, öğretim gereçlerinin geliştirilmesi (çalışma yaprakları, etkinlik tasarlama, tepegöz saydamları, slaytlar, görsel medya (VCD, DVD) gereçleri, bilgisayar temelli gereçler), eğitim yazılımlarının incelenmesi, çeşitli nitelikteki öğretim gereçlerinin değerlendirilmesi, internet ve uzaktan eğitim, görsel tasarım ilkeleri, öğretim materyallerinin etkinlik durumuna ilişkin araştırmalar, Türkiye'de ve dünyada öğretim teknolojilerinin kullanım durumu oluşturmaktadır (YÖK, 2016:9). Öğretmen adaylarının iki ve üç boyutlu materyaller geliştirmelerine olanak sağlayan bu tür bir ders, onların üst düzey düşünme becerilerinin ortaya çıkarılması açısından önemli hale gelmektedir. Nitekim Öztürk ve Öztürk (2015) tarafından yürütülen, tarih öğretmen adaylarının öğretim teknolojileri ve materyal tasarımı dersinde hazırladıkları materyaller ile ilgili çalışmalarını ve bu derse ilişkin görüşlerini belirledikleri çalışmada; "Öğretim Teknolojileri ve Materyal Tasarımı" dersinin amaçlarına ilişkin görüşleri olarak öğretmen adaylarının \%23.72'lik kısmı düşünme ve yaratıcılığı geliştirme cevabını vermiştir. Materyal oluşturma sürecinde özellikle tasarı aşamasında öğretmen adaylarının kendi ön yaşantılarını ve yaratıcılıkla ilgili yeteneklerini birleştirmeleri gerektiği belirtilmektedir (Yanpar ve Yıldırım, 1999).

Yaratıcılıkla ilgili yetenekler genellikle akıcılık, esneklik, orijinallik, eksiklikleri algılama yeteneği, ayrıntılara inme ve yeniden tanımlama olarak belirtilmektedir (Torrance, 1965). Yaratıcılık kavram olarak birçok araştırmacı tarafından farklı şekillerde tanımlanmıştır. Bu kavrama yönelik standart tanımlamalar orijinallik ve etkililik özelliklerini içermektedir (Runco ve Jeager, 2012). Torrance (1965) yaratıcılığı; problemlere duyarlı olma, eksiklikler, bilgide olan boşluklar, eksik unsurlar, uyumsuzluklar sonucunda zorlukları belirleme, çözümler için araştırma yapma, tahminlerde bulunma veya eksiklikler ile ilgili hipotezler formüle etme, hipotezleri test etme, onlar üzerinde değişiklik yaparak yeniden test etme ve sonuçlarla bağlantı kurma süreci olarak tanımlamaktadır. Stenberg ve Lubart'a (1998) göre ise yaratıcılık; yeni ve uygun çalışma üretebilme yeterliliğidir. Yeni kavramı orijinal, beklenmeyen vb. kavramları, uygun kavramı ise kullanışlı, adapte edilmiş vb. kavramları ifade etmektedir (Stenberg ve Lubart, 1998). Birçok araştırmacı ise yaratıcılığın tanımlanmasında yaratıcı süreç, yaratıcı ürün, yaratıcı kişi ve yaratıcı çevre boyutlarının iki veya daha fazla yönünü bir araya getirmektedir (Hu ve Adey,2002). Runco ve Kim (2013) yaratıcı kişilik ve yaratıcı süreç ile ilgili özellikleri şu şekilde açıklamaktadırlar: Yaratıcı kişiliklerin temel karakteristikleri; deneyime açıklık, geniş ilgi alanları olma, özerklik, bağdaşmama, içsel ilgi alanları olmadır. Fakat kişi bakış açısından yaratıcılık tamamen kişiliğe odaklanmamıştır. Aynı zamanda kişisel eğilimleri ve kapasiteleri de içermektedir. Bunlardan bazıları entelektüel, mizaç veya tutum, diğerleri alışkanlık, değerler ve benlik kavramını yansıtır. Runco ve Kim (2013) yaratıcı süreç için aşamalı olarak en iyi bilinen modelin Wallas (1926) tarafından özetlendiğini ve bu aşamaların ise hazırlık, kuluçka, ilham 
ve doğrulama olduğunu belirtmektedirler. Hazırlık aşamasında bireyler problemleri belirleyip çözüme ulaştırabilecek bilgileri toplarlar. Kuluçka aşaması bireylere problemlere geri dönüp çözümler, alternatifler ve ilgili deneyimler üzerinde düşünme fırsatı sunmaktadır. İlham aşaması fikrin kendini bilinen yaptığı durumda bir anda ortaya çıkmaktadır. Doğrulama aşamasında ise yeni fikirler veya çözümler dikkatle değerlendirilmeli ve çalışır durumda oldukları test edilmelidir. Yaratıcı çevre ise yaratıcı süreç ve ürüne olanak tanıyan ortam olarak belirtilmektedir (O'Quin ve Besemer, 1999). O’Quin ve Besemer (1999) yaratıcı ürünlerde şu bileşenleri dile getirmektedirler. İlki ürünlerde yenilik, orijinallik veya ürün içinde yeni bir şeyin gösterilmesidir. İkinci önemli bileşen ürünün değeri veya kullanışlıı̆ı veya bir problemi çözme derecesidir. Yaratıcı ürünün tanımlanmasında bu bilinen iki önemli bileşene ek olarak çoğu kez gözden kaçırılan üçüncü unsur, ürünün stili, zarafeti veya estetik niteliğidir. Bireyin yaratıcı bir ürünün ortaya koyabilmesi için de yaratıcı düşünmesi gereklidir.

Yaratıcı düşünme; buluş, yenilik arayan ya da önceki sorunlara yeni çözümler oluşturan ve özgün düşüncelerin ortaya çıkmasını sağlayan bir düşünce biçimidir (Yenilmez ve Yolcu, 2007). Yaratıcı düşünme daha çok zihinsel etkinlikleri, yaratıcılık ise hem zihinsel hem de performansa dayalı etkinlikleri çağrıştırmaktadır (Demirel, 2005). Guilford (1950), yaratıcı düşünme sürecinin tanımlanmasında ıraksak düşünmeyi anahtar bir kavram olarak belirtmektedir. Iraksak düşünme; eski düşüncelerden vazgeçmeyi, yeni bağlantılar kurmayı, bilginin sınırlarını genişletmeyi ve olağanüstü düşünceleri başlatmayı içerir (Üstündağ, 2002:45). Yakınsak düşünme ise, sorunlar karşısında insanların bir tek çözüm yolunu görmeleri ve diğerlerini dikkate almamaları demektir (Üstündag, 2002:19). Dünyada ve ülkemizde önemi fark edilen yaratıcı düşünmeye ve yaratıcılığa ilişkin birçok araştırma yapılmıştır. Bu araştırmaların genellikle bireysel özellikler ve yaratıcılık arasındaki ilişki, öğretim uygulamalarının yaratıcı düşünme becerisi üzerindeki etkileri üzerine yoğunlaştığı görülmektedir. Örneğin, Sayan ve Hamurcu (2011) ilköğretim dördüncü sınıf fen ve teknoloji dersi için geliştirilen materyallerin öğrencilerin yaratıcı düşünme becerilerine ve öz kavramlarına etkileri araştırmışlardır. Deney grubu 38, kontrol grubu 38 olmak üzere toplam 76 öğrenci ile yürütülen araştırmada; kontrol grubunda fen ve teknoloji derslerinde fen ve teknoloji ders kitabı ve çalışma kitabındaki etkinlikler uygulanmıştır. Deney grubunda ise, fen ve teknoloji ders kitabı ve çalışma kitabındaki etkinlikler yanında araştırmacı tarafından geliştirilmiş olan çalışma yaprakları, sunular, saydamlar, eğitsel oyunlar, levhalar vb. materyaller kullanılmıştır. Araştırmanın sonucunda fen ve teknoloji dersi için geliştirilmiş olan materyallerin yaratıcılığın alt boyutu olan esneklik boyutunda pozitif yönde etkileri olduğu görülmüştür. Koçoğlu ve Köymen (2003) tarafından yürütülen araştırmada ilköğretim okulu 6. ve 7. sınıf öğrencilerinin hiperortam tasarımcısı olarak katıldığı öğrenme çevresine katılan (deney grubu) ve katılmayan (kontrol grubu) grupların Torrance Yaratıcı Düşünme Testinden aldıkları son test puanları arasında anlamlı bir fark olup olmadığını sınanmıştır. Deney grubu ile kontrol grubunun Torrance Yaratıcı Düşünme Testinden aldıkları sözel ve şekilsel son test puanları arasında deney grubu lehine 
anlamlı fark ortaya çıkmıştır. Yenilmez ve Çalışkan (2011), ilköğretim okullarında 6, 7 ve 8. sınıflarda okuyan 278 öğrencinin çoklu zekâ alanları ile yaratıcı düşünme düzeyleri arasında ilişki olup olmadığını belirlemişlerdir. Veriler "Çoklu Zekâ Envanteri", "Yaratıcı Düşünme Becerisi Ölçeği" ve araştırmacılar tarafından hazırlanan demografik bilgi formu aracılığı ile toplanmıştır. Araştırma sonucunda, yaratıcı düşünme düzeyi ile görsel-uzamsal zekâ, müziksel-ritmik zekâ, bedensel kinestetik zekâ, kişilerarası-sosyal zekâ ve içsel zekâ arasında pozitif yönde anlamlı ancak zayıf bir ilişki saptanmıştır. Ulukök, Sarı, Özbek ve Çelik (2012), 199 fen ve teknoloji öğretmen adayının kendi algılarına göre yaratıcılık düzeylerinin; sınıf düzeyi, yaş, anne-baba eğitim durumu ve ailenin gelir durumuna göre farklılaşma olup olmadığını araştırmışlardır. Çalışmada veri toplama aracı olarak, öğrenci tanıtım formu ve Ne Kadar Yaratıcısınız? yaratıcılık ölçeği kullanılmıştır. Araştırmanın sonuçlarına göre fen ve teknoloji öğretmen adaylarının yaratıcılık düzeylerinde sınıf düzeyi, yaş ve anne eğitim durumu değişkenleri arasında anlamlı bir farklılık tespit edilirken; baba eğitim durumu ve ailenin gelir durumu değişkenleri açısından anlamlı bir farklılık ortaya çıkmamıştır. Gülel (2006) sınıf öğretmeni adaylarının kendi algılarına göre yaratıcılık düzeylerini belirlemiştir. 109 öğretmen adayı ile gerçekleştirilen araştırmada Ne Kadar Yaratıcısınız? yaratıcılık ölçeği kullanıımıştır. Araştırmanın sonucunda bayan öğrencilerin yaratıcılık düzeylerinin bay öğrencilere göre daha yüksek olduğu saptanmıştır. Sınıf öğretmeni adaylarının ilkokul, ortaokul ve lise akademik başarı algılarına göre yaratıcılık düzeylerinde anlamlı bir farklılık bulunmamıştır. Ancak üniversite akademik başarı algılarına göre yaratıcılık düzeylerinde anlamlı bir farklılık bulunmuştur. Aynı zamanda enstrüman çalmayanların, çalanlara göre daha yaratıcı oldukları bulunmuştur. Kurtuluş (2012) ise fen ve teknoloji dersi kapsamında yaratıcı düşünmeye dayalı öğretim uygulamalarının öğrencilerin bilimsel yaratıcılık, bilimsel süreç becerileri ve akademik başarılarına etkisini incelemiştir. Altıncı sınıfta bulunan 48 öğrenci ile yürütülen araştırmada fen ve teknoloji öğretim programında yer alan 'Vücudumuzda Sistemler' ünitesi, deney grubuyla yaratıcı düşünmeye dayalı öğretim uygulamaları ile kontrol grubuyla ise fen ve teknoloji öğretim programına dayalı öğretim uygulamaları ile işlenmiştir. Veri toplama aracı olarak Bilimsel Yaratıcılık Testi, Bilimsel Süreç Beceri Testi ve 'Vücudumuzda Sistemler' ünitesi için geliştirilmiş Akademik Başarı Testi kullanılmıştır. Uygulama sonrasında deney ve kontrol grubu öğrencilerinin bilimsel yaratıcılık, bilimsel süreç beceri ve akademik başarı test puanlarının deney grubu lehine anlamlı bir şekilde farklılaştığı belirlenmiştir.

Literatürde öğretmen adaylarıyla gerçekleştirilen ve öğretim teknolojileri ve materyal tasarımı dersi kapsamında yaratıcı düşünmeyi ele alan araştırmaların sayısı oldukça sınırlıdır. Oysa öğretmen adaylarının yaratıcı düşünme beceri düzeylerine yönelik algılarını belirlemek, onların bu becerilerinin gelişimine katkı sağlayacak öğrenme ortamlarının oluşturulması ve düzenlenmesi adına önem arz etmektedir. Ayrıca yaratıcı düşünme ile ilgili mevcut çalışmalarda; genellikle yaratıcılık ile ilgili testler aracılığı ile sadece nicel veriler elde edildiği dikkati çekmektedir. Bu çalışma kapsamında öğretmen adaylarının görüşlerinden doğrudan alıntılara yer verilmesi, 
konu ile ilgili daha derinlemesine bilgi sağlanması adına literatüre katkı sağlayacaktır. Literatürde demografik özelliklerin yaratıcı düşünmeye etki ettiğini gösteren çalışmaların (Can Yaşar ve Aral, 2011; Çetingöz, 2002; Pilar Matud, Rodríguez ve Grande, 2007) olması sebebi ile bu çalışma kapsamında cinsiyet ve mezun olunan okul türü unsurları da dikkate alınmıştır. Araştırmada aşağıdaki sorulara yanıt aranmıştır:

1. Fizik öğretmen adaylarının yaratıcı düşünme becerilerine yönelik algıları nasıldır?

2. Fizik öğretmen adaylarının yaratıcı düşünme becerilerine yönelik algılarının cinsiyete göre dağılımı nasıldır?

3. Fizik öğretmen adaylarının yaratıcı düşünme becerilerine yönelik algılarının mezun oldukları okul türüne göre dağılımı nasıldır?

4. Bir öğretim materyalinin yaratıcı olması fizik öğretmen adaylarına ne ifade etmektedir?

5. Fizik öğretmen adayları kendi oluşturdukları öğretim materyallerini yaratıcılık açısından nasıl değerlendirmektedirler?

6. Fizik öğretmen adaylarının öğretim teknolojileri ve materyal tasarımı dersinin yaratıcı düşünme süreçlerine etkisine ilişkin görüşleri nelerdir?

\section{Yöntem}

\section{Araştırma Deseni}

$\mathrm{Bu}$ araştırma fizik öğretmen adaylarının yaratıcı düşünme becerilerine ve yaratıcı materyallere yönelik algılarını belirlemeye yönelik betimsel bir çalışmadır.

\section{Çalışma Grubu}

Araştırmanın çalışma grubunu, öğretim teknolojileri ve materyal tasarımı dersini alan 57 fizik öğretmen adayı oluşturmaktadır. Bu öğretmen adayları 5. Sınıf olup 37 si bayan 20 si erkektir. Araştırmanın dördüncü, beşinci ve altıncı problemlerine yönelik gerçekleştirilen görüşmelere bu öğretmen adaylarından gönüllü olan 27 öğretmen adayı katıım göstermiştir.

Çalışma grubundaki kişilerin kimliklerini gizli tutmak amacıyla; öğretmen adaylarına $\ddot{O}_{1}, \ddot{O}_{2}, \ddot{O ̈}_{3}$ şeklinde kodlar verilmiştir.

\section{Uygulama}

Araştırmacı literatür araştırması yaparak öğretmen adaylarına öncelikle lise öğrencilerinin fizikte anlamakta zorluk çektikleri konuları ve kavram yanılgılarını belirtmiştir. Öğretmen adaylarından okul deneyimi kapsamında gittikleri okullardaki lise fizik öğretmenlerinden bu konudaki deneyimlerini yaptıkları görüşmeler aracılığı ile tespit etmeleri istenmiştir. Öğretmen adaylarına lise öğrenim dönemlerinde kendi öğrencilik deneyimlerini de göz önünde bulundurmaları belirtilmiştir. Tüm bu bilgiler ışığında öğretmen adayları hangi konuda nasıl bir materyal tasarlayacaklarına karar 
vermişlerdir. Öğretmen adaylarına öğretim teknolojileri ve materyal tasarımı dersi kapsamında teorik olarak materyal tasarlama ve hazırlama ilkeleri anlatılmıştır. Daha önce hazırlanmış materyaller üzerinde doğru ve yanlış hususlar öğretmen adayları ile tartışılmıştır. Seçtikleri konunun kazanımları, materyal tasarlama ve hazırlama ilkeleri doğrultusunda materyallerini hazırlamışlardır. Materyallerinin ders sürecinde uygulanabilirliğini mikro öğretim ile test etmişlerdir. Mikro öğretimin ardından öğretmen adayları kendi materyal ve uygulamalarını değerlendirmişlerdir. Aynı zamanda öğretim üyesi ve öğretmen adayının öğrenci konumundaki arkadaşları da materyal ve uygulamaya yönelik görüşlerini paylaşmışlardır. Öğretmen adayları ile birlikte yapılan bu değerlendirmeler materyalin tasarlama, hazırlama ve uygulama ölçütleri esas alınarak gerçekleştirilmiştir.

\section{Verilerin Toplanması}

Veri toplama aracı olarak, araştırmacı tarafından araştırmanın ilk üç problemine yönelik bilgi formu, diğer problemler için ise yarı-yapılandırılmış bir görüşme formu geliştirilmiştir. Soruların hazırlanma sürecinde yaratıcılık ile ilgili literatür incelenmiş, öğretim teknolojileri ve materyal tasarımı dersini yürüten araştırmacının ders içi gözlemleri dikkate alınmıştır. Bilgi formunda öğretmen adaylarının cinsiyetleri, mezun oldukları okul türü ve kendilerini hangi düzeyde yaratıcı düşünme becerisine sahip olarak algıladıkları sorulmuştur. Görüşme formunda ise; bir öğretim materyalinin yaratıcı olmasının kendilerine ne ifade ettiği, kendi oluşturdukları materyalleri yaratıcılık açısından nasıl değerlendirdikleri ve öğretim teknolojileri ve materyal tasarımı dersinin yaratıcı düşünme süreçlerine etkisine ilişkin görüşleri sorulmuştur. Soruların içerik geçerliliği için alan eğitiminde uzman iki öğretim üyesinin görüşüne başvurulmuştur. Dönütler sonucunda araştırmacı ve öğretim üyeleri sorular üzerinde görüş birliğine varmışlardır.

\section{Verilerin Analizi}

Bilgi formundaki sorulardan elde edilen veriler frekans ve yüzde olarak sunulmuştur. Görüşme formu sorularından elde edilen verilerde nitel veri analizlerinden betimsel analiz yaklaşımı esas alınmıştır. Toplanan verilerden ortaya çıkan kavramlar düzenlenerek kodlamalar yapılmıştır. Veriler üç hafta sonra tekrar kodlanmış ve kodlamalar arasındaki tutarlılığı hesaplamak için Miles ve Huberman'ın (1994) önerdiği uyuşum yüzdesi formülü $(P=(\mathrm{Na} / \mathrm{Na}+\mathrm{Nd}) \times 100)$ kullanılmıştır. Uyuşum yüzdesi 91,07 hesaplanmıştır.

\section{Bulgular ve Yorum}

$\mathrm{Bu}$ bölümde araştırma problemleri doğrultusunda elde edilen düzenlenmiş veriler tablolar halinde sunulmuştur. Görüşmelerden elde edilen verilerin analizi sonucu oluşan kodlamaları daha açık hale getirmek, öğretmen adaylarının görüşlerini yansıtmak amacıyla öğretmen adaylarının cevaplarından doğrudan alıntılara da yer verilmiştir.

Araştırmanın birinci problemi ile ilgili olarak öğretmen adaylarının yaratıcı düşünme beceri düzeylerine yönelik algıları frekans ve yüzde olarak Tablo 1 de 
sunulmuştur. Tablo 1 incelendiğinde; kendisini "orta düzeyde yaratıcı" olarak algılayan öğretmen adaylarının sayısı en fazladır. Bu düzeyi "ortanın üzerinde yaratıcı" düzeyi takip etmektedir. Kendisini "olağanüstü yaratıcı" düzeyinde algılayan öğretmen adaylarının sayısı en azdır. Bu düzeyden sonraki en az sayı "ortanın altında yaratıcı" düzeyine aittir.

Tablo 1. Öğretmen adaylarının yaratıcı düşünme becerilerine yönelik algıları

\begin{tabular}{lcc}
\hline Yaratıcı düşünme beceri düzeyi & $\mathbf{f}$ & $\%$ \\
\hline Olağanüstü Yaratıcı & 1 & 1,8 \\
Oldukça Yaratıcı & 10 & 17,5 \\
Orta Düzeyde Yaratııı & 24 & 42,1 \\
Ortanın Altında Yaratıcı & 2 & 3,5 \\
Ortanın Üzerinde Yaratıcı & 20 & 35,1
\end{tabular}

Öğretmen adaylarının yaratıcı düşünme becerilerine yönelik algılarının cinsiyete göre dağılımını frekans ve yüzde olarak gösteren Tablo 2 incelendiğinde; bayan öğretmen adaylarııın en fazla "orta düzeyde yaratıcı" kategorisinde, erkek öğretmen adaylarının ise en fazla "orta düzeyde yaratııı" ve "ortanın üzerinde yaratıcı" kategorilerinde eşit olarak yer aldığı görülmektedir.

Tablo 2. Öğretmen adaylarının yaratıcı düşünme becerilerine yönelik algılarının cinsiyete göre dağııımı

Yaratıcı düşünme düzeyleri

\begin{tabular}{|c|c|c|c|c|c|c|}
\hline \multirow[t]{2}{*}{ Cinsyet } & & \multirow{2}{*}{$\begin{array}{l}\text { Olağanüstü } \\
\text { Yaratıcı }\end{array}$} & \multirow{2}{*}{$\begin{array}{l}\text { Oldukça } \\
\text { Yaratıcı }\end{array}$} & \multirow{2}{*}{$\begin{array}{l}\text { Orta } \\
\text { Düzeyde } \\
\text { Yaratıcı }\end{array}$} & \multirow{2}{*}{$\begin{array}{l}\text { Ortanın } \\
\text { Altında } \\
\text { Yaratıcı }\end{array}$} & \multirow{2}{*}{$\begin{array}{l}\text { Ortanın } \\
\text { Üzerinde } \\
\text { Yaratıcı }\end{array}$} \\
\hline & & & & & & \\
\hline \multirow[t]{2}{*}{ bayan } & $f$ & & 5 & 17 & 2 & 13 \\
\hline & $\%$ & & $\% 13,5$ & $\% 45,9$ & $\% 5,4$ & $\% 35,1$ \\
\hline \multirow[t]{2}{*}{ erkek } & $f$ & 1 & 5 & 7 & & 7 \\
\hline & $\%$ & $\% 5,0$ & $\% 25,0$ & $\% 35,0$ & & $\% 35,0$ \\
\hline
\end{tabular}


Öğretmen adaylarının yaratıcı düşünme becerilerine yönelik algılarının mezun oldukları okul türüne göre dağııımını frekans olarak gösteren Tablo 3 incelendiğinde; genel liseden mezun olan öğretmen adaylarının en fazla "ortanın üzerinde yaratıcı" ve "orta düzeyde yaratıcı" kategorilerinde yer aldığı görülmektedir. Anadolu lisesinden mezun olan öğretmen adayları en fazla "ortanın üzerinde yaratııı" kategorisinde bulunmaktadır. Meslek lisesi ve süper liseden mezun olan öğretmen adayları ise "orta düzeyde yaratıcı" kategorisinde yer almaktadırlar.

Tablo 3. Öğretmen adaylarının yaratıcı düşünme becerilerine yönelik algılarının mezun oldukları okul türüne göre dağılımı

Yaratıcı düşünme düzeyleri

\begin{tabular}{|c|c|c|c|c|c|}
\hline \multirow{4}{*}{$\begin{array}{l}\text { Mezun olunan } \\
\text { okul türü }\end{array}$} & & & \multirow{2}{*}{$\begin{array}{l}\text { Orta } \\
\text { Düzeyde }\end{array}$} & \multirow{2}{*}{$\begin{array}{l}\text { Ortanın } \\
\text { Altında }\end{array}$} & \multirow{2}{*}{$\begin{array}{l}\text { Ortanın } \\
\text { Üzerinde }\end{array}$} \\
\hline & Olağanüstü & Oldukça & & & \\
\hline & Yaratıcı & Yaratıcı & Yaratıcı & Yaratıcı & Yaratıcı \\
\hline & $f$ & $f$ & $f$ & $f$ & $f$ \\
\hline Açık lise & & 1 & & & \\
\hline Meslek lisesi & & 1 & 2 & & 1 \\
\hline Genel lise & & 6 & 10 & 2 & 11 \\
\hline Süper lise & & 1 & 6 & & 2 \\
\hline Anadolu lisesi & 1 & 1 & 4 & & 6 \\
\hline Özel lise & & & 2 & & \\
\hline
\end{tabular}

Bir öğretim materyalinin yaratıcı olmasının öğretim teknolojileri ve materyal tasarımı dersini alan fizik öğretmen adaylarına ne ifade ettiğine yönelik araştırmanın dördüncü problemi kapsamında öğretmen adaylarının cevapları kodlanmıştır. Bu kodlar ve kodlara ait frekanslar Tablo 4 te sunulmuştur. Kodlamalardan bir materyalin yaratıcı olması öğretmen adaylarına en fazla orijinal olmasını ifade ettiği görülmektedir. Orijinal olmayı sıralama olarak materyalin dikkat çekici olması ve amaca hizmet etmesi özellikleri takip etmektedir.

Tablo 4. Bir öğretim materyalinin yaratıcı olmasının fizik öğretmen adaylarına ne ifade ettiğine yönelik görüşlere ait kodlamalar

\begin{tabular}{lc}
\hline Kodlamalar & $\mathbf{f}$ \\
Öğretici (Ö1, Ö2) & 2 \\
Akılda kalıcılık sağlayan tasarım (Ö1, Ö6) & 2 \\
Konuyla bütünlük sağlaması (Ö2) & 1 \\
Kavram yanılgılarını gidermesi (Ö2, Ö13) & 2 \\
Eldeki malzemelerden ekonomik tasarım (Ö2, Ö4) & 2 \\
\hline
\end{tabular}


Orijinal (Ö2, Ö3, Ö5, Ö6, Ö7, Ö8, Ö9, Ö10, Ö11, Ö14, Ö15, Ö20, Ö22, Ö26,

Ö27)

Dikkat çekici (Ö3, Ö5, Ö8, Ö16, Ö18, Ö21, Ö24)

7

Soyut kavramları somutlaştıran (Ö4)

1

Amaca hizmet eden (Ö5, Ö6, Ö7, Ö12, Ö17, Ö25) 6

Günlük yaşamla ilişkili (Ö8, Ö16) 2

Görselliği iyi (Ö8, Ö9) 2

İlginç (Ö9)

Kullanışlılık (Ö15)

Değişik (Ö17, Ö18) 2

Etkileyici (Ö19) 1

Gerçeğe yakınlık (Ö23)

Merak uyandırıcı (Ö24) 1

Bir öğretim materyalinin yaratıcı olmasının; orijinal, dikkat çekici olmasını ve amaca hizmet etmesini ifade ettiğine yönelik fizik öğretmen adaylarının görüşlerinden bazıları aşağıdaki gibidir:

Ö7: "Bir materyalin yaratıcı olması; alışılmış olanın, bilinenin dışında, farklı, yeni, özgün olmasıdır..."

Ö21: "Yaratıcı bir materyal dersi seven ya da sevmeyen tüm öğrencilerin dikkatini çekebilmelidir..."

Ö25: "Bir materyalin yaratıcı olması amaca yönelik olarak geliştirilmiş olması gerektiğini ifade ediyor..."

Öğretmen adaylarının kendi oluşturdukları materyalleri yaratııılık açısından nasıl değerlendirdiklerine ilişkin kodlamaların yer aldığı Tablo 5 incelendiğinde; kendi materyalini yaratıcı bulan öğretmen adaylarının sayısının en fazla olduğu görülmektedir. Bu öğretmen adayları materyallerinin yaratıcı olmasına gerekçe olarak en çok materyallerinin dikkat çekici olma özelliğini ifade etmişlerdir. Materyallerini yaratıcı bulmayan öğretmen adayları ise en fazla orijinal olmamayı gerekçe olarak belirtmişlerdir.

Tablo 5. Fizik öğretmen adaylarının kendi oluşturdukları materyalleri yaratıcılık açısından değerlendirmelerine yönelik kodlamalar

\begin{tabular}{lc}
\hline Kodlamalar & $\mathbf{f}$ \\
Yaratıcı & 12 \\
Gerekçeler & \\
$>\quad$ Amaca hizmet ediyor (Ö1) & \\
$>\quad$ Tüm ayrıntılar dikkate alınarak malzeme seçildi ve & materyali \\
tasarlandı (Ö1) & \\
$>$ Önceki örneklere bakılarak yapılmadı (Ö2) & \\
$>$ Öğrencilerin öğrenmesini sağlayacak (Ö12) & \\
\hline
\end{tabular}


> Konudaki kavram yanılgılarını giderecek (Ö13)

$>$ Birbirinden farklı malzemelerle birçok işlevi olan tasarlandı (Ö15)

$>$ Değişik (Ö18)

> Gerçek yaşamla ilişkilendirildi (Ö23)

$>\quad$ Dikkat çekici (Ö8, Ö21, Ö24, Ö26)

$>$ Orijinal (Ö25)

$>\quad$ Akılda kalıcılığı sağlayacak özellikte (Ö26)

\section{Orta düzeyde yaratıcı}

Gerekçeler

$>\quad$ Benzeri daha önce yapıldı (Ö3, Ö9, Ö11)

$>$ Herkesin aklına gelebilecek nitelikte fakat görsellik olarak yeterli (Ö8)

\section{Yaratıcı değil}

Gerekçeler

$>\quad$ Başka materyalden fikir alındı (Ö10)

$>\quad$ Görselde farklılıklar yapılabilirdi (Ö17)

$>\quad$ Orijinal değil (Ö6, Ö7, Ö20, Ö22)

$>$ Hayranlık uyandırabilecek, farklı bakış açısı sağlayabilecek nitelikte değil (Ö4)

Çok yaratıcı değil

Gerekçeler

$>\quad$ Orijinal değil (Ö14)

$>\quad$ Çok etkileyici değil (Ö19)

B Başkasından yardım alındı (Ö27)

Oldukça yaratıcı

Gerekçe

> Günlük yaşamla ilişkili ve dikkat çekici (Ö16)

Kendi materyalini yaratıcı bulan öğretmen adaylarının gerekçe olarak materyallerinin dikkat çekici olma özelliğini, materyallerini yaratıcı bulmayan öğretmen adaylarının ise orijinal olmamayı belirten gerekçelerine yönelik görüşlerinden bazıları aşağıdaki gibidir:

Ö26: "Materyalimin yaratıcı olduğunu düşünüyorum. Lise öğrencilerinin dikkatini çekebilecek..."

Ö7: “...Daha önce tasarlanmış olduğu için yaratıcı değildi.”

Ö20: "...Materyallerim daha önce yapılmış çalışmalardı. Yaratıcı oldukları söylenemez."

Öğretmen adaylarının öğretim teknolojileri ve materyal tasarımı dersinin yaratıcı düşünme süreçlerine etkisine ilişkin görüşlerine yönelik kodlamaların yer aldığı Tablo 6, dersin yaratıcı düşünme süreçlerinde etkili olduğunun düşünenlerin sayıca en fazla olduğunu göstermektedir. Bu öğretmen adaylarının dersin çok yönlü düşünmeyi ve hayal etmeyi sağlama, üretmeye, araştırmaya, sorgulamaya, fikir 
üretmeye teşvik etme gibi niteliklerini belirttikleri görülmektedir. Sadece iki öğretmen adayı kısmen cevabını vermiştir.

Tablo 6. Fizik öğretmen adaylarının öğretim teknolojileri ve materyal tasarımı dersinin yaratıcı düşünme süreçlerine etkisine ilişkin görüşlerine yönelik kodlamalar

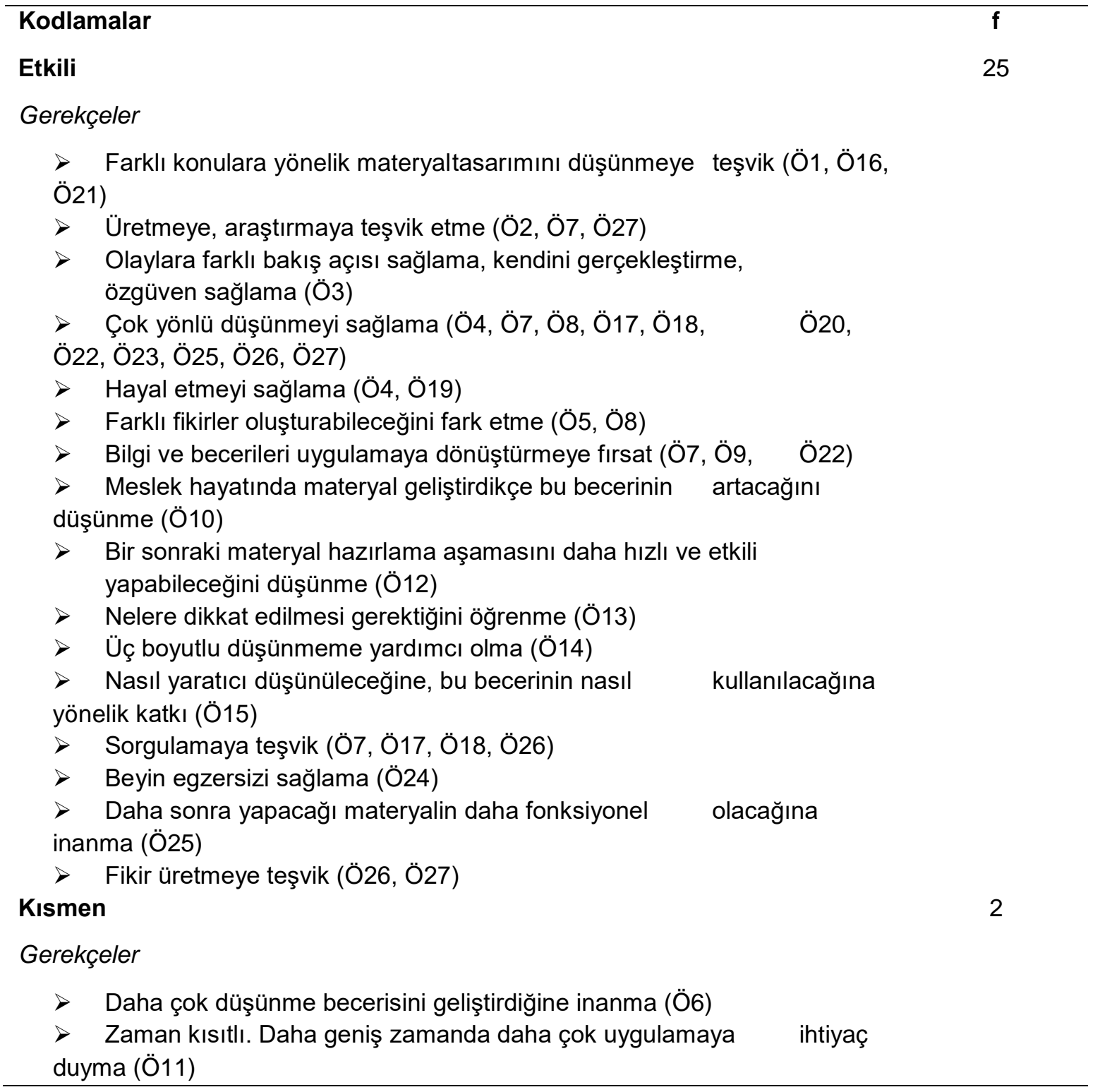

Öğretim teknolojileri ve materyal tasarımı dersinin yaratıcı düşünme süreçlerine etkisine ilişkin fizik öğretmen adaylarının görüşlerinden bazıları aşağıdaki gibidir:

Ö25: "Evet etkili olduğunu düşünüyorum. Çünkü çok yönlü düşünme becerisi kazandırdığına inanıyorum..."

Ö19: "Yaratıcı düşünme becerimi geliştirdiğini düşünüyorum. Konular hakkında kafamızı yorarak, düşünerek materyallerimizi geliştirdik. Bu da hayal etmemizi sağladı."

Ö7: "Kesinlikle var. Yıllardır ezberci, sıradan ve yeni bir şeyler katmayı öğrenemeden bir eğitim aldık. Sorgulatan bir ders. Öğrencinin materyal 
tasarlayabilmek için araştırması gerekiyor. Neden?, Niçin?, Nasıl? şeklinde sorgulamasını öğretiyor. Çok yönlü düşünmeyi öğretiyor...”

\section{Sonuç ve Tartışma}

Bu araştırma fizik öğretmen adaylarının yaratıcı düşünme becerilerine ve yaratıcı materyallere yönelik algılarını belirlemek, öğretim teknolojileri ve materyal tasarımı dersinin yaratıcı düşünme süreçlerine etkisi konusunda fizik öğretmen adaylarının görüşlerini almak amacı ile yapılmıştır. Elde edilen veriler fizik öğretmen adaylarının kendilerini çoğunlukla "orta düzeyde yaratıcı" olarak değerlendirdiklerini göstermektedir. Öğretmen adaylarının yaratıcı düşünme becerilerine yönelik algılarının cinsiyete göre dağıımı incelendiğinde; bayan öğretmen adaylarının en fazla "orta düzeyde yaratıcı" kategorisinde, erkek öğretmen adaylarının ise en fazla "orta düzeyde yaratıcı" ve "ortanın üzerinde yaratıcı" kategorilerinde eşit olarak yer aldığı belirlenmiştir. Genel liseden mezun olan öğretmen adaylarının en fazla "ortanın üzerinde yaratıcı" ve "orta düzeyde yaratıcı" kategorilerinde, Anadolu lisesinden mezun olan öğretmen adaylarının en fazla "ortanın üzerinde yaratıcı" kategorisinde, meslek lisesi ve süper liseden mezun olan öğretmen adaylarının ise "orta düzeyde yaratıcı" kategorisinde yer aldığı ortaya çıkmıştır. Öğretmen adaylarının farklı liselerden mezun olmalarına rağmen benzer yaratıcı düzeylerinde yer almalarında; aynı üniversite ve bölümü kazanıp beş yıldır aynı öğrenme sürecini paylaşmalarının etkisi olabilir.

Bir öğretim materyalinin yaratıcı olması; fizik öğretmen adaylarına en fazla orijinal olması, dikkat çekici olması ve amaca hizmet etmesi özelliklerini çağrıştırmaktadır. O'Quin ve Besemer (1999) de yaratıcı ürünlerde orijinallik, kullanışılık ve görsellik unsurlarının olması gerektiğini belirtmektedir. Materyalini yaratıcı bulan öğretmen adaylarının sayısı en fazla olup bu görüşlerini destekleyici olarak en çok materyallerinin dikkat çekici olma özelliğini ifade etmişlerdir. Yani bu çalışmadaki fizik öğretmen adayları yaratıcı ürünlerde olması gereken görsellik unsurunu ön planda tutmuşlardır. Materyalini yaratıcı bulmayan öğretmen adaylarının çoğu ise bu görüşlerine materyallerinin orijinal olmamasını gerekçe göstermişlerdir. Yanpar ve diğ. (2006) tarafından gerçekleştirilen, sınıf öğretmenliği ve sosyal bilgiler öğretmenliği bölümlerinde öğretim teknolojileri ve materyal tasarımı dersini alan öğretmen adaylarının elle ve bilgisayar temelli yapmış oldukları ders materyallerinin yaratıcılık yönünden incelenmesini amaçlayan araştırmada da materyalini yaratıcı bulan öğretmen adaylarının en fazla olduğu belirlenmiştir. Öğretmen adayları materyallerinin yaratıcı olduğu görüşlerini destekleyici olarak kendilerinin yapması, çaba harcamaları, benzersiz ve orijinal bulmaları, tasarımda özgünlük gibi ifadeleri kullanmışlardır.

Öğretim teknolojileri ve materyal tasarımı dersinin yaratıcı düşünme süreçlerine etkisi konusunda fizik öğretmen adaylarının büyük bir çoğunluğu olumlu yönde görüş bildirmiştir. Bu görüşlerini dersin çok yönlü düşünmeyi ve hayal etmeyi sağladığı, üretmeye, araştırmaya, sorgulamaya ve fikir üretmeye teşvik ettiği ifadeleri ile desteklemişlerdir. Öğretmen adaylarının bu ifadelerinin kaynağı, ders kapsamında 
kendi materyallerini tasarlama, hazırlama ve uygulama süreçlerini bizzat yaşamaları olabilir. Acer (2011) tarafından okulöncesi öğretmenliğinde öğrenim gören öğretmen adaylarının öğretim teknolojileri ve materyal tasarımı dersine ilişkin görüşlerinin belirlenmesi amacı ile yürütülen araştırmada da öğretmen adayları en çok yaratıcılıklarının geliştiğini ve yaratıcı ürünler tasarlayabildiklerini belirtmişlerdir. Bununla birlikte dersin çok yönlü düşünmeye katkısı olduğu da öğretmen adaylarının görüşleri arasında yer almıştır. Benzer şekilde Çakır (2010) öğretim teknolojileri ve materyal tasarımı dersini alan Türkçe öğretmenliği öğrencilerinin ders ile ilgili görüşlerini aldığı araştırmasında; dersin yaratıcılıklarını geliştirdiği yönündeki görüşlerini ortaya koymuştur. Ince, Usta ve Çığır Dikyol (2010) fen ve sosyal bilgiler öğretmen adaylarının materyal tasarlamadaki yaratıcılıklarını belirlemek amacıyla gerçekleştirdikleri araştırmada; Eğitim Fakültesi öğrencilerinin kendi materyallerini geliştirme sürecinin yaratıcılıklarını artırabileceği ve daha etkili eğitim materyalleri tasarlamalarına yardımcı olabileceği sonucuna ulaşmışlardır. Bu araştırmada dersin yaratıcı düşünme süreçlerine kısmen etkisi olduğunu düşünen öğretmen adaylarından biri yaratıcı düşünme becerisini geliştirmekten ziyade sadece düşünme becerisini geliştirdiğine inandığını belirtmiştir. Diğer öğretmen adayı ise yaratıcı düşünme için daha geniş zamanda daha çok uygulamaya ihtiyaç bulunduğunu dile getirmiştir. Runco ve Kim (2013) de yaratıcı çalışmalar için zamanın önemli bir faktör olduğunu, zaman sınırlıı̆ının bazı öğrenciler için yaratıcı süreci kısıtlayan bir durum olabildiğini belirtmektedirler. Bu nedenle böyle bir çalışma sürecinin öğretim teknolojileri ve materyal tasarımı dersi kapsamında sadece bir dönem boyunca yürütülmesi bu iki öğretmen adayına yeterli gelmemiş olabilir.

Öğretmen adaylarının yaratıcı düşünme beceri algılarını orta düzeyden daha yukarı taşımak için bu becerilerini geliştirebilecekleri eğitim ortamlarının oluşturulması önem arz etmektedir. Eğitim Fakültelerinin programlarında yer alan özellikle öğretim teknolojileri ve materyal tasarımı dersi öğretmen adaylarının yaratıcı düşünme becerilerini farkına varabilmelerine ve yaratıcılıklarını geliştirebilmelerine olanak sağlayabilir. Nitekim öğretim teknolojileri ve materyal tasarımı dersini alan öğrenciler ile yürütülen literatürdeki bazı çalışmalar (Acer, 2011; Çakır, 2010; İnce, Usta ve Çığır Dikyol, 2010; Sönmez vd., 2006) bu görüşü destekleyici sonuçlara ulaşmışlardır. Sönmez ve diğ. (2006), öğretim teknolojileri ve materyal tasarımı dersi ile fen bilgisi ve fizik öğretmen adaylarının öğretme-öğrenme açısından kazandıkları deneyimlerini değerlendirdikleri çalışmada; öğretmen adaylarının bu ders ile klasik öğrenme modelinden farklı olarak üretken ve yaratıcı öğretmen modeline göre yetiştirildiklerini düşündüklerini ortaya çıkarmışlardır.

Sonuç olarak bu çalışma kapsamındaki fizik öğretmen adaylarının yaratıcı düşünme beceri algıları orta düzey olarak çıkmıştır. Bu düzeyi daha yukarıya taşımak adına tüm pedagojik derslerde öğretmen adaylarııı yaratıcı düşünmelerini geliştirmeye yönelik alıştırmalar yapılabilir. Böylelikle daha uzun zaman dilimine yayılacak bu tür alıştırmaların etki boyutu araştırılabilir. 


\section{Kaynaklar}

Acer, D. (2011). Okulöncesi öğretmen adaylarının materyal geliştirme dersine ilişkin görüşlerinin incelenmesi. İlköğretim Online, 10(2), 421-429.

Can Yaşar, M. \& Aral, N. (2011). Altı yaş çocuklarının yaratıcı düşünme becerilerine sosyo-ekonomik düzey ve anne baba öğrenim düzeyinin etkisinin incelenmesi. Kuramsal Egitimbilim, 4(1), 137-145.

Çakır, Ö. (2010). Materyal geliştirmede mikro-öğretim: öğretmen adaylarının yöntem ve geribildirimler üzerine görüşleri. Adıyaman Üniversitesi Sosyal Bilimler Enstitüsü Dergisi, 3(5), 55-73.

Çetingöz, D. (2002). Okulöncesi eğitimi öğretmenliği öğrencilerinin yaratıcı düşünme becerilerinin gelişiminin incelenmesi. Yayımlanmamış Yüksek Lisans Tezi. Dokuz Eylül Üniversitesi.

Demirel, Ö. (2005). Eğitimde yeni yönelimler, Ankara: Pegem A Yayıncılık.

Guilford, J.P. (1950). Creativity. American Psychologist, 5, 444-454.

Gülel, G. (2006). Sınıf öğretmeni adaylarının yaratıcılık düzeylerinin çeşitli değişkenler açısından incelenmesi (Pamukkale Üniversitesi örneği) Yayımlanmamış Yüksek Lisans Tezi. Pamukkale Üniversitesi Sosyal Bilimler Enstitüsü.

Hu, W. \& Adey, P. (2002). A scientific creativity test for secondary school students, International Journal of Science Education, 24(4), 389-403.

İnce, E., Usta, S. \& Çığır Dikyol, D. (2010). The social and science teacher candidates' creativity on material using and designing. Procedia Social and Behavioral Sciences, 2, 3463-3467.

Koçoğlu, Ç. \& Köymen, Ü. (2003). Öğrencilerin hiperortam tasarımcısı olarak katıldığı öğrenme çevresinin yaratıcı düşünmeye etkisi. The Turkish Online Journal of Educational Technology, 2(3), 127-136.

Kurtuluş, N. (2012). Yaratıcı düşünmeye dayalı öğretim uygulamalarının bilimsel yaratıcılık bilimsel süreç becerileri ve akademik başarıya etkisi. Yüksek Lisans Tezi. Karadeniz Teknik Üniversitesi Eğitim Bilimleri Enstitüsü.

Miles, M. B. \& Huberman, A. M. (1994). Qualitative data analysis. London: Sage Publications.

Öztürk, T. \& Öztürk, F. Z. (2015). Tarih öğretmen adaylarının "öğretim teknolojisi ve materyal tasarımı" dersine yönelik uygulamaları ile görüşlerinin incelenmesi. eKafkas Eğitim Araştırmaları Dergisi, 2(3), 63-78.

O'Quin, K. \& Besemer, S. P. (1999). Creative products. M. A. Runco \& S. R. Pritzker (Ed.) Encyclopedia of creativity, Vol 1 (s. 413-423). USA: Academic Press.

Pilar Matud, M., Rodríguez, C. \& Grande, J. (2007). Gender differences in creative thinking. Personality and Individual Differences, 43(5), 1137-1147. 
Runco, M. A. \& Jeager, G. J. (2012). The standard definition of creativity. Creativity Research Journal, 24(1), 92-96.

Runco, M. A. \& Kim, D. (2013). Four Ps of creativity and recent updates. E.G. Carayannis (Ed.) Encyclopedia of creativity, invention, innovation, and entrepreneurship (s. 755-759). New York: Springer.

Sayan, Y. \& Hamurcu, H. (2011). İlköğretim dördüncü sınıf fen ve teknoloji dersi için geliştirilen materyallerin öğrencilerin yaratıcı düşünme becerilerine ve öz kavramlarına etkileri. 2nd International Conference on New Trends in Education and Their Implications. Siyasal Kitabevi. Ankara: Türkiye.

Sönmez, E., Dilber, R., Alver, B., Aksakallı, A. \& Karaman, İ. (2006). Öğretim teknolojileri ve materyal geliştirme dersinin öğrenci açısından önemine yönelik bir araştırma. Kazım Karabekir Eğitim Fakültesi Dergisi, 13, 113-119.

Sternberg, R.J. \& Lubart, L.A. (1998). The concept of creativity: prospects and paradigms. R.J. Sternberg (Ed.) Handbook of creativity (s. 3-15).Cambridge: Cambridge University Press.

Torrance, E. P. (1965). Scientific views of creativity and factors affecting its growth. Daedalus, 94(3), 663-681.

Ulukök, Ş., Sarı, U., Özbek, G. \& Çelik, H. (2012). Fen ve teknoloji öğretmen adaylarının yaratıcılık düzeylerinin demografik değişkenler açısından incelenmesi (Kırıkkale Üniversitesi örneği). Eğitim ve Öğretim Araştırmaları Dergisi, 1(3), 202-212.

Üstündag, T. (2002). Yaratıcılığa Yolculuk, Ankara: Pegem A Yayıncılık.

Wallas, G. (1926). The art of thought. New York: Harcourt, Brace and Company.

Yanpar, T. \& Yıldırım, S. (1999). Öğretim teknolojileri ve materyal geliştirme. Ankara: Anı Yayıncılık.

Yanpar, T. Koray, Ö., Parmaksız, R. Ş. \& Arslan, A. (2006). İlköğretim öğretmen adayları tarafından hazırlanan el yapımı ve teknoloji temelli materyallerin yaratıcılık boyutları açısından incelenmesi. Educational Administration: Theory and Practice, 45, 129-148.

Yenilmez, K. \& Çalışkan, S. (2011). İlköğretim öğrencilerinin çoklu zekâ alanları ile yaratıcı düşünme düzeyleri arasındaki ilişki. Dicle Üniversitesi Ziya Gökalp Eğitim Fakültesi Dergisi, 17, 48-63.

Yenilmez, K. \& Yolcu, B. (2007). Öğretmen davranışlarının yaratıcı düşünme becerilerinin gelişimine katkısı. Sosyal Bilimler Dergisi. 18, 95-105.

YÖK (2016). Egitim Fakültesi Ögretmen Yetistirme Lisans Programları. Fen Bilgisi Öğretmenliği

Lisans

Programı. http://www.yok.gov.tr/documents/10279/49665/fen bilgisi/f385bc7822df-497d-bfca-7aee80c75c22 adresinden Nisan 2016'da ulaşılmıştır. 